\title{
Present Status and Future Prospects of Bio-Agents in Agriculture
}

\author{
Nandani Shukla*, Erayya Archana Negi Akansha Singh, \\ B.C. Kabadwa, Roopali Sharma and Jatinder Kumar \\ Department of Plant Pathology, College of Agriculture, G.B. Pant University of Agriculture \& \\ Technology, Pantnagar-263 145, India \\ *Corresponding author
}

\section{A B S T R A C T}

\begin{abstract}
Managing agricultural production systems on a sustainable basis is one of the most critical challenges for the future of humanity as the world population is increasing exceptionally. Concepts of modern technologies in agricultural systems have given an important role for the improvement of agricultural productions e.g. crop yield, livestock production, aquaculture production, and sustainable agriculture, in order to maintain food security. Protection of crops against plant diseases, have an evident role to play to meet the rising demand for food quality and quantity (Strange and Scott, 2005). Approximately, direct yield losses caused by pathogens, animals, and weeds, are altogether responsible for losses ranging between 20 and $40 \%$ of global agricultural productivity (Oerke, 2006). Therefore, in order to meet the growing food demand, about 15-20 times increase in the use of synthetic pesticides will be required (Oerke, 2006) but the excessive use of synthetic pesticides is no longer sustainable and causes land, air and water contamination and also responsible for causing resistance development in pathogens and insects as well as adverse impacts on natural enemies and humans (Birch et al., 2011). Due to strong consumer demands to address food security and environmental safety has resulted in the lesser use of synthetic pesticides, the lowering of maximum residue limits and changes in the regulatory environment that favour more environmentally safe control options. Thus there is need to switch for more environmentally safe and ecologically sound pest control methods such as bioagents/biopesticides.
\end{abstract}

Keywords

Bio-Agents, Agriculture field, Plant diseases

Article Info

Accepted:

17 March 2019

Available Online:

10 April 2019

\section{Introduction}

The global population is projected to reach 8.5 billion by $2030,9.7$ billion by 2050 and exceed 11 billion in 2100 (UN. World Population Prospects, 2011). There is continued need for pest management in agriculture, with pressure continuously increasing on agriculture to achieve higher yield from limited or even lesser land (UN.
World Population Prospects, 2011). Pests (which include invertebrates, pathogens and weeds) are estimated to cause between $27 \%$ and $42 \%$ losses in production for major crops around the world, but this would rise to a staggering 48-83\% without crop protection (Oerke, 2006). Therefore, in order to meet the growing food demand, about 15-20 times increase in the use of synthetic pesticides will be required (Oerke, 2006) but the excessive 
use of synthetic pesticides is no longer sustainable and causes land, air and water contamination and also responsible for causing resistance development in pathogens and insects as well as adverse impacts on natural enemies and humans (Birch et al., 2011). Due to strong consumer demands to address food security and environmental safety has resulted in the lesser use of synthetic pesticides, the lowering of maximum residue limits and changes in the regulatory environment that favour more environmentally safe control options. Thus there is need to switch for more environmentally safe and ecologically sound pest control methods such as bioagents/biopesticides. Biopesticide is a term that has been applied with a narrow focus on preparations containing living microorganisms, through to a broader definition that encompasses botanical compounds and semiochemicals (e.g. pheromones) (Kiewnick, 2007). In this chapter, we are restricted to microbial pest control agents (bacteria, viruses, fungi, protozoa and nematodes) and/or bioactive compounds (such as metabolites) produced directly from these microbes, which are used to suppress populations of pests, including insects, pathogens and weeds. Biopesticides are the formulations of bioagents in a form which keep the organism at higher count and viable for their introduction or application in the field (Van, 2012).

Many microorganisms in biopesticides also deliver a number of benefits beside virulence to a target pathogen. For example, Trichoderma species are known to enhance the uptake of soil macro and micro nutrients by plants (Harman, 2011) and specific isolates can deliver substantial plant growth benefits in the absence of a disease (Clouston. et al., 2010). Entomopathogenic fungi can also have antagonistic activity against plant pathogens attacking the same crop (Ownley et al., 2010).
There is recent evidence that endophytic microorganisms which provide protection against diseases, can also provide abiotic stress (drought and salt) tolerance attributes to certain crops (Shukla et al., 2012; Rawat et al., 2011). Benefits in addition to pest control can be an important selection criterion in screening programs to choose commercially attractive biocontrol isolates (Ko"hl et al., 2011) and open up a significant opportunity for marketing biopesticides as products with an added value. The interest in biopesticides is based on the advantages associated with such products which are: (i) inherently less harmful and less environmental load, (ii) designed to affect only one specific pest or, in some cases, a few target organisms, (iii)often effective in very small quantities and often decompose quickly, thereby resulting in lower exposures and largely avoiding the pollution problems and (iv)when used as a component of Integrated Pest Management (IPM) programs, biopesticides can contribute greatly. Besides, biopesticides have the following benefits

\begin{tabular}{|l|l|}
\hline Factors & $\begin{array}{l}\text { Benefits of } \\
\text { biopesticides }\end{array}$ \\
\hline $\begin{array}{l}\text { 1. Cost effectiveness } \\
\text { 2. Persistence and residual } \\
\text { effect }\end{array}$ & $\begin{array}{l}\text { Costlier but reduced } \\
\text { number of applications } \\
\text { Low, mostly } \\
\text { biodegradable and self }\end{array}$ \\
3. Knockdown effect & perpetuating \\
4. Handling and Bulkiness \\
5. Pest resurgence & Delayed \\
6. Resistance, & Bulky; Carrier based; \\
7. Effect on beneficial & Easy; \\
flora fiquid & formulation \\
8. Target specificity & Less \\
9. Waiting time & Less prone \\
10.Nature of control & Less harmful on \\
11.Shelf life & beneficial \\
& Mostly host specific \\
& Almost nil \\
& Preventive \\
& Less \\
\hline
\end{tabular}

Negative impact of chemicals has brought into focus the use of safer and effective alternative such as bioagents/biopesticides. Various microorganisms are currently being 
utilized as bioagents are Trichoderma spp., Pseudomonas fluorescence, Bacillus spp., Ampelomyces quisqualis, Agrobacterium radiobacter, nonpathogenic Fusarium, Coniothyrium, and atoxigenic Aspergillus niger (Singh. et al., 2014 and Keswani et al., 2015). India has huge potential for the growth of industry as it losses crops of worth US\$ 9259 million every year due to low consumption of pesticides in the country (https://www.mordorintelligence.com/).

Biopesticides are derived from microorganisms and other natural sources, and are an eco-friendly alternative to the synthetic pesticides. As next generation pesticides, biopesticides are gaining popularity in India.

Due to presence of higher pesticides residues in food crops, specifically on grains and increasing pest resistance, developed countries are posing strict regulations on use of some synthetic pesticides, which will affect the use of synthetic pesticides and will promote the use of biopesticides in the region. Other factors driving the growth of the market are the ecofriendly nature of biopesticides, constructive public support policies, increasing public awareness and lesser development of pest resistance.

The significance of biopesticides in integrated pest management (IPM) system has also increased its popularity in India. However, the domestic market has been plagued by factors hindering the potential growth of biopesticides, such as non-availability, lesser reach and continuing disappearance of mixed/multiple cropping that adversely affects demand for biopesticides.

\section{Historical perspective}

Historically, biopesticides came into existence because of environmental pollution concerns coupled with chemical pesticides. It is expected that plant extracts were probably the most primitive agricultural biopesticides, use of nicotine to control plum beetles was recorded as early as the 17th century. Use of white-muscadine fungus (Beauveria bassiana) to cause an infectious disease in silkworm was recorded by Agostine Bassi way back in 1835 . Experiments with mineral oils as plant protectants were also reported in the 19th century. During the early 20th century, an ever-growing number of studies and proposal for biopesticides were developed (Chen 2014).

The first widely used biopesticide included spores of the bacteria Bacillus thuringiensis (Bt) isolated from a diseased silkworm by Japanese biologist Shigetane Ishiwata in 1901 (Chen 2014, Glare et al., 2000). Ten years later, Ernst Berliner in Thuringen, Germany rediscovered it in a diseased caterpillar of flour moth. The Bt pathogen was classified in 1911 as type species Bacillus thuringiensis and remains the most widely used biopesticide till date. In the early 1920s, the French began to use $\mathrm{Bt}$ as a biological insecticide and the first commercially available Bt product, Sporeine, appeared in 1938. In the US in the $1950 \mathrm{~s}$, widespread use of biopesticides began to take hold. In the later half of the 20th century, research and development continued at a low level because of the widespread adoption of cheaper but more toxic synthetic chemical insecticides. During this time, new products were developed and applied; especially in niche markets where petroleum based chemicals were not registered, not effective, or not economical. For example, in 1956, the Pacific Yeast Product Company developed an industrial process known as submerged fermentation, which allowed production of $\mathrm{Bt}$ on a large scale (Glare et al., 2000). In 1973, Heliothis NPV was granted exemption from tolerance and the first viral insecticide, Elcar 
received a label in 1975. In 1977, Bacillus thuringiensis var. israelensis (toxic to flies) was discovered, and in 1983 the strain tenebrion is (toxic to beetles) was found. In 1979, the U.S. EPA registered the first insect pheromone for use in mass trapping of Japanese beetles. In the 1990s, researchers began testing kaolin clay as an insect repellent in organic fruit orchards. It was made commercially available, particularly for use in organic systems, in 1999 (Marrone et al., 2002).

Biopesticide development for the control of plant diseases has undergone a similar transformation. During the early 20th century, studies of soil microbiology and ecology had led to the identification of many different microorganisms that act as antagonists or hyperparasites of pathogens and insect pests. A number of these were shown to be useful in field-scale inoculations, but few were developed commercially because of the rapid adoption of chemical pesticides during that time period (Chen 2014). Research into biological control of insect pests and pathogens slowed after the discovery of synthetic pesticide molecules during/after World War II. Renewed interest in biological pest management was stimulated following the demonstration by environmentalists and ecologists that broad and repeated application of these synthetic molecules could be ecologically harmful (Cook and Baker 1983). Commercial success stories from the 1980s and 1990s include products containing Agrobacterium radiobacter for the prevention of crown gall on woody crops and Pseudomonas fluorescens for the prevention of fire blight in orchards where the streptomycin had been overused and resistant pathogen populations were abundant. In the greenhouse and potting mix industry, products containing a variety of microbes that suppressed soilborne pathogens were introduced into the market.
The genus Trichoderma was discovered by Persoon in 1794 but captured the attention only after Weindling and his associates showed that one species of the genus can kill other fungi and control plant diseases (Weindling 1932 and 1934). However, the first field success of biological control (target Sclerotium rolfsii) using Trichoderma was not until the 1970s (Weindling 1934). Applied and fundamental research on these fungi has continued since in biotechnology and agriculture.

\section{Present scenario and future projection}

Presently, biopesticides cover only $2 \%$ of the plant protectants used globally; however its growth rate shows an increasing trend in past two decades. Agricultural biologicals have recorded double-digit sales growth and have accrued around US \$2.3 billion in annual sales over the past few years (Cuddeford and Kabaluk, 2010). Around two-thirds of US $\$ 2.3$ billion is contributed by microbial formulations alone (Cuddeford and Kabaluk 2010).

The global market of bioagents is expected to reach $\$ 4$ billion by 2024 from $\$ 2$ billion in 2016, growing at a CAGR of $8.8 \%$ from 2016 to 2024 (Fig. 1). Similarly, global investment in biopesticides was US\$1.3 billion in 2011 and is estimated to reach US \$ 3.2 billion by 2017 , with at $15.8 \%$ compound annual growth rate from 2012 to 2017 (www. markets and markets.com). These formulations include live microbial cells and microbial active ingredients for seed treatment and foliar applications (www. naasindia.org). There are about 1400 biopesticides currently sold globally, and is estimated that the annual growth rate of the biopesticide sector is greater than that of synthetic pesticides (16\% versus 3\%) (www. naasindia.org). The USA accounts for $40 \%$ of the global biopesticide use, followed by 
Europe (20\%) and Oceania (20\%) (www.naasindia.org). However, the usage of bioagents is only about $20 \%$ of that of synthetic fertilizers (www.fao. org).

In India, biopesticide industry is projected to grow at a CAGR of $20.2 \%$ since $2010-2020$. Scope of Current market for pesticides was US\$ 23.92 million in 2015 which represent only $4.2 \%$ of the overall pesticide market. Currently, 34 microorganism have been included in the schedule of Gazette of India for registration as biopesticide with Central Insecticide Board, Faridabad, under section 9 (3B) and 9(3) of the insecticide act 1968 (Table 1) (Keswani et al., 2015). Over 150 Bio pesticide producing companies, 15 types of bio pesticides out of 227 pesticides are registered. Highest demand for bio pesticides was observed from West India - Maharashtra followed by South India. Microbial pesticides sale are dominated by Trichoderma viride, Pseudomonas fluorescens and Bacillus thuringensis, (Ken research Report 2015). Central insecticide Board and registration Committee, Government of India have registered more than 970 Bio pesticide product. More than 63 Indian Private Companies with Registered Products. Some Major Indian Companies for Bio pesticides: Pest Control (Pvt) Ltd; Multiplex Biotech Ltd., International Panacea, Biotech International Ltd; T. Stanes; etc.

The biopesticides market has been segmented in different ways. On the basis of type, the biopesticides market is led by the bioinsecticides segment, followed by the bioherbicides, biofungicides, and bionematicides segments and others (sulfur, oil, insect repellent, moth control, and other biochemicals) respectively. The bioinsecticides segment is projected to be the fastest-growing type in the biopesticides market, due to the high crop loss by pests and diseases (Fig. 2).
On the basis of crop type, classified as Grains $\&$ oilseeds, Fruits \& vegetables, Others (turf, plantation, sugar crops, cotton, and ornamental crops). The market for fruit \& vegetable crops accounted for the largest share and is also projected to be the fastestgrowing. This is mainly due to a high demand for fruits \& vegetables by the growing population across the world. Biopesticides market share from fruits \& vegetables accounted for over $70 \%$ of the overall industry revenue (www. markets and markets.com). As many fruits \& vegetables are eaten without proper processing, consumers demand for better crop safety processing. Pesticide residue is generally a concern among consumers in these crops than in row crops that are not consumed in raw form. This practice leads to a high increase in pressure on grocery stores and good marketers to offer pesticide-free fruits \& vegetables. Grains \& oil seeds will observe gains over $6 \%$ up to 2024 (www.naasindia.org). Oats, vegetables, grains, and oilseeds are majorly contributing crops. The products prevent the generation of pathogens in the yield and enhance crop productivity. Other segment includes pulses, turfs, forage, and greenhouse crops.

The different modes of applications for biopesticides are foliar spray, soil treatment, seed treatment, and post-harvest. Foliar spray is highly used for applying biopesticides. To improve quality of crops and increase productivity of plants, foliar spray is effectively used to control pests on crops. The increases in acceptance of biological microbes and smart farming techniques have proven to be a major driving factor for the foliar application. These are marketed as dry and Liquid formulation (www. markets and markets.com).

On the basis of Origin, it is classified as Microbial pesticides, Biochemical pesticides, 
Beneficial insects, Plant-incorporated protectants and lastly, by geography the biopesticides market is segmented on the basis of region into North America, Europe, Asia-Pacific, and the Rest of the World (RoW). The U.S, Mexico and Canada are covered under North America wherein Europe covers France, Germany, Italy, Spain and others. Asia pacific covers China, India, Japan and others and rest of the World (RoW) covers South America, Middle East and Africa. In 2015, North America accounted for the largest market share in the biopesticides market, followed by Europe and Asia-Pacific. U.S. and Canada constituted the largest country-level markets in the North American region in 2015 (ken research report, 2015). Increase in awareness about the benefits of biopesticides, among the cultivators and rise in population is leading to the growth of the market in this region. The biopesticides market in the Asia-Pacific region is projected to grow with investments from several multinational manufacturers. The market is projected to grow due to the increase in agricultural technologies and agricultural exports of key products. Moreover, extensive $R \& D$ initiatives have been undertaken for exploring the new varieties of biopesticides to be used on different pest management and soil fertility to increase the yield.

\section{Research and development in biopesticide based pest management}

Out of all the biopesticides used today, microbial biopesticides constitute the largest group of broad-spectrum biopesticides, which are pest specific (i.e., do not target non-pest species and are environmentally benign). Over 200 microbial biopesticides are available in 30 countries affiliated to the Organization for Economic Co-operation and Development (OECD) (Kabaluk and Gazdik 2007). There are 53 microbial biopesticides registered in the USA, 22 in Canada and 21 in the European Union (EU) (Kiewnick, 2007 and PMRA. In) although reports of the products registered for use in Asia are variable (Thakore, 2006). Overall, microbial biopesticide registrations are increasing globally, the expansion of various technologies has increased the scope for more products and the change in the trend to develop microbial products is definitely on the rise (Bailey et al., 2010 and Kristiofferesen et al., 2008).

\section{Bacterial biopesticides}

The bacteria that are used as biopesticides can be divided into four categories: crystalliferous spore formers (such as Bacillus thuringiensis); obligate pathogens (such as Bacillus popilliae); potential pathogens (such as Serratia marcesens); and facultative pathogens (such as Pseudomonas aeruginosa).Out of these, the spore formers have been most widely adopted for commercial use because of their safety and effectiveness. The most commonly used bacteria are B. thuringiensis and Bacillus sphaericus. B. thuringiensis is a specific, safe and effective tool for insect control (Roy et al., 2007).

It is primarily a pathogen of lepidopterous pests like American bollworm in cotton and stem borers in rice. When ingested by pest larvae, Bt releases toxins which damage the mid gut of the pest, eventually killing it. Main sources for the production of BT preparations are the strains of the subspecies kurstaki, galeriae and dendrolimus. Other species of bacteria have little impact on pest management though some commercial products based on Agrobacterium radiobacter, B. popilliae, B. subtilis, Pseudomonas cepacia, Pseudomonas chlororaphis, Pseudomonas flourescens, Pseudomonas solanacearum and Pseudomonas syringae are available (Table 2). 


\section{Viral biopesticides}

Over 700 insect-infecting viruses have been isolated, mostly from Lepidoptera (560) followed by Hymenoptera (100), Coleoptera, Diptera and Orthoptera (40) (Khachatourians 2009). About a dozen of these viruses have been commercialized for use as biopesticides (Table 2). The viruses used for insect control are the DNA-containing baculoviruses (BVs), Nucleopolyhedrosis viruses (NPVs), granuloviruses (GVs), acoviruses, iridoviruses, parvoviruses, polydnaviruses, and poxviruses and the RNA-containing reoviruses, cytoplasmic polyhedrosis viruses, nodaviruses, picrona-like viruses and tetraviruses. However, the main categories used in pest management have been NPVs and GVs. These viruses are widely used for control of vegetable and field crop pests globally, and are effective against plantchewing insects. Their use has had a substantial impact in forest habitats against gypsy moths, pine sawflies, Douglas fir tussock moths and pine caterpillars.

Codling moth is controlled by Cydia pomonella GVs on fruit trees (Lacey et al., 2008) and potato tuberworm by Phthorimaea operculella GVs in stored tubers (Arthurs et $a l$., 2008). Virus-based products are also available for cabbage moths, corn earworms, cotton leafworms and bollworms, beet armyworms, celery loopers and tobacco budworms (Table 2). Baculoviruses are target specific viruses which can infect and destroy a number of important plant pests. They are particularly effective against the lepidopterous pests of cotton, rice and vegetables. Their large-scale production poses certain difficulties, so their use has been limited to small areas. They are not available commercially in India, but are being produced on a small scale by various IPM centres and state agricultural departments.

\section{Fungal biopesticides}

Some of the most widely used species include Trichoderma harzianum, Trichoderma viridae, Streptomyces griseoviridis, Verticillium chlamydosporium, Beauveria bassiana, Metarhizium anisopilae, Nomuraea rileyi, Paecilomyces farinosus and Verticillium lecanii etc. Many of them have been commercialized globally (Table 2). Trichoderma is a fungicide effective against soil borne diseases such as root rot. It is particularly relevant for dryland crops such as groundnut, black gram, green gram and chickpea, which are susceptible to these diseases. Preparation of Trichoderma biopesticide is cheap and requires only basic knowledge of microbiology. This biofungicide is recommended as seed treatment, soil application, soil drenching, root dip technique etc for the control of seed and soil borne diseases. Many Trichoderma strains, mainly $T$. harzianum, $T$. viride and $T$. virens (formerly Gliocladium virens), have been identified as having potential applications in biological control and a partial list of genera of plant pathogenic fungi affected by Trichoderma includes: Armillaria, Botrytis, Chondrostereum, Colletotrichum, Dematophora, Diaporthe, Endothia, Fulvia, Fusarium, Fusicladium, Helminthosporium, Macrophomina, Monilia, Nectria, Phoma, Phytophthora, Plasmopara, Pseudoperonospora, Pythium, Rhizoctonia, Rhizopus, Sclerotinia, Sclerotium, Venturia, Verticillium, and wood rot fungi (Singh, 2014). Recent studies also indicate potential use of Trichoderma strains in abiotic stress management i.e., drought and salt stress (Shukla et al., 2012 and Rawat et al., 2011)

\section{Nematode biopesticides}

Another group of microorganisms that can control pests is the entomopathogenic nematodes, which control weevils, gnats, 
white grubs and various species of the Sesiidae family (Klein, 1990; Shapiro-Ilan et al., 2002; Grewal, 1990). These fascinating organisms suppress insects in cryptic habitats (such as soil-borne pests and stem borers). Commonly used nematodes in pest management belong to the genera Steinernema and Heterorhabditis, which attack the hosts as infective juveniles (IJs) (Kaya and Gaugler, 1993; Koppenhofer and Kaya, 2002).

\section{Protozoan biopesticides}

Although they infect a wide range of pests naturally and induce chronic and debilitating effects that reduce the target pest populations, the use of protozoan pathogens as biopesticide agents has not been very successful. Protozoa are taxonomically subdivided into several phyla, some of which contain entomogenous species. Microsporan protozoans have been investigated extensively as possible components of integrated pest management programmes.

\section{Opportunities in India}

Harmful impact of chemicals such as higher pesticides residues in food crops, specifically on grains and increasing pest resistance has brought into focus the use of safer and effective alternative such as bioagents/biopesticides. Moreover, the area under organic crop cultivation is on the rise because of the growing demand of organic food, a result of increasing health consciousness among the people. This indicates that there is huge scope for growth of the biopesticide sector. Analysts believe that there would be a greater development in the biopesticides sector (Desai 1997). Due to its rich biodiversity India offers plenty of scope in terms of sources for natural biological control organisms as well as natural plant based pesticides. The rich traditional knowledge base available with the highly diverse indigenous communities in India may provide valuable clues for developing newer and effective biopesticide. The National Farmer Policy 2007 has strongly recommended the promotion of biopesticides for increasing agricultural production, sustaining the health of farmers and environment. It also includes the clause that biopesticides would be treated at par with chemical pesticides in terms of support and promotion. Increased adoption further depends on-

1. Concrete evidences of efficacy of biopesticides in controlling crop damage and the resultant increase in crop yield

2. Availability of high quality products at affordable prices

3. Strengthening of supply chain management in order to increase the usage of biopesticides. In this regard, an efficient delivery system from the place of production (factory) to place of utilization (farm) of biopesticides is quite essential.

\section{Future prospects:}

The biopesticide market will continue to grow in future due to increased pest resistance problem and high demand of safe and quality food products. However, there are many challenges that will need to be overcome.

Biopesticides clearly draw attention as safer alternative to manage pest and diseases while posing less risk to human being and the environment. In the US, biopesticides are monitored by Environmental Protection Agency which supports their registration, sale and distribution under the Federal Insecticide, Fungicide, and Rodenticide Act (FIFRA), as well as ensures a "reasonable certainty of no harm" under the Federal Food, Drug, and 
Cosmetic Act (FFDCA) to provide pesticide residue-free food and feed (Leahy et al., 2014). Most of the times, it is the farmers who are affected by the problems of pesticide resistance and withdrawal of plant protection products, and yet they are 'policy takers' rather than 'policy makers'. Hence, a publicprivate sector approach to the development, manufacturing and sale of environment friendly alternatives to chemical pesticides for developing countries like India is the need of the day.

Table.1 Microbial pesticides included in the schedule to the Insecticide Act, 1968

\begin{tabular}{|c|c|c|}
\hline Bacterial & Fungal & Viral \\
\hline Burkholderia cepacia & Verticillium chlamydosporium & Grannulosis viruses \\
\hline $\begin{array}{l}\text { Agrobactarium radiobacter } \\
\text { strain } 84\end{array}$ & Streptomyces griseoviridis & $\begin{array}{l}\text { Nuclear Polyhedrosis } \\
\text { Viruses }(N P V)\end{array}$ \\
\hline \multicolumn{3}{|l|}{ Agrobactarium tumefaciens } \\
\hline $\begin{array}{l}\text { Erwinia amylovora (hairpin } \\
\text { protein) }\end{array}$ & Streptomyces lydicus & \\
\hline Alcaligenes spp & Candida oleophila & \\
\hline $\begin{array}{l}\text { Photorhabdus } \\
\text { luminescences } \\
\text { strain K-1 }\end{array}$ & $\begin{array}{lll}\text { Fusarium } & \text { oxysporum } \\
\text { pathogenic) } & \end{array}$ & \\
\hline $\begin{array}{l}\text { Photorhabdus } \\
\text { luminescences }\end{array}$ & Penicilliuim islanidicum & \\
\hline Serratia marcescens GPS 5 & Pythium oligandrum & \\
\hline Bacillus subtilis & VAM (Fungus) & \\
\hline \multirow[t]{14}{*}{ Pseudomonas florescence } & Aspergillus niger - strain AN27 & \\
\hline & Beauvaria bassiana & \\
\hline & Metarrhizium anisopliae & \\
\hline & Verticillum lecanii & \\
\hline & Trichoderma harzianum & \\
\hline & Nomurea rileyi & \\
\hline & Hirsutella species & \\
\hline & Ampelomyces quisqualis & \\
\hline & Phlebia gigantean & \\
\hline & Coniotyrium minitans & \\
\hline & Myrothecium verrucaria & \\
\hline & Paecilomyces lilacinus & \\
\hline & Chaetomium globosum & \\
\hline & Piriformospora indica & \\
\hline
\end{tabular}


Table.2 Commercial microbial biopesticides developed for plant disease management

\begin{tabular}{|c|c|c|c|c|}
\hline $\begin{array}{l}\text { Mirco- } \\
\text { organism }\end{array}$ & Target pest & Action & Brand name & Producer \\
\hline \multicolumn{5}{|c|}{ Bacteria } \\
\hline A. radiobacter & Crown galls & Antagonist & $\begin{array}{l}\text { Galltrol-A } \\
\text { Dygall } \\
\text { Norbac 84-C* } \\
\text { Nogall }\end{array}$ & $\begin{array}{l}\text { AgBioChem } \\
\text { Agbioresearch } \\
\text { Ltd } \\
\text { New BioProducts } \\
\text { Becher } \\
\text { Underwood }\end{array}$ \\
\hline B. pumilus & $\begin{array}{l}\text { Effective against } \\
\text { rust, downy and } \\
\text { powdery } \\
\text { mildews }\end{array}$ & Fungicide & $\begin{array}{l}\text { Ballad } \\
\text { Sonata AS } \\
\text { YeildShield }\end{array}$ & $\begin{array}{l}\text { Agraquest Inc. } \\
\text { Gustafson LLC }\end{array}$ \\
\hline B. subtilis & $\begin{array}{l}\text { Effective against } \\
\text { root rot caused } \\
\text { by Rhizoctonia, } \\
\text { Fusarium, } \\
\text { Alternaria, } \\
\text { Aspergillus and } \\
\text { Pythium Also } \\
\text { effective against } \\
\text { some foliar } \\
\text { diseases }\end{array}$ & $\begin{array}{l}\text { Fungicide and } \\
\text { antagonist }\end{array}$ & $\begin{array}{l}\text { Serenade } \\
\text { Epic } \\
\text { Kodiak } \\
\text { MBI } 600 \\
\text { Companion** } \\
\text { Cillus } \\
\text { Green-all G } \\
\text { HiStich N/T** } \\
\text { Subtiex }\end{array}$ & $\begin{array}{l}\text { AgraQuest, Inc. } \\
\text { Gustafson, Inc. } \\
\text { Growth Products } \\
\text { Green Biotech, } \\
\text { Korea } \\
\text { Becker } \\
\text { Underwood }\end{array}$ \\
\hline $\begin{array}{l}\text { B. subtilis } \\
\text { FZB24 }\end{array}$ & $\begin{array}{l}\text { Effective against } \\
\text { Rhizoctonia, } \\
\text { Fusarium, } \\
\text { Alternaria, } \\
\text { Verticillium and } \\
\text { Streptomyces on } \\
\text { vegetables and } \\
\text { ornamental } \\
\text { plants }\end{array}$ & Fungicide & $\begin{array}{l}\text { Rhizo-Plus } \\
\text { Rhizo-Plus } \\
\text { Konz }\end{array}$ & $\begin{array}{l}\text { FZB Biotechnik, } \\
\text { GmbH }\end{array}$ \\
\hline $\begin{array}{l}\text { Erwinia } \\
\text { amylovora } \\
\text { (Hrpn harpin } \\
\text { protein) }\end{array}$ & Multi-spectrum & $\begin{array}{l}\text { Insecticide, } \\
\text { fungicide and } \\
\text { nematicide }\end{array}$ & Messenger & Eden Biosciences \\
\hline P. cepacia & $\begin{array}{l}\text { Effective against } \\
\text { soil pathogenic } \\
\text { fungi }\end{array}$ & Toxic & Intercept & Soil Tech \\
\hline P. chlororaphis & $\begin{array}{l}\text { Effective against } \\
\text { fungal } \\
\text { pathogens of } \\
\text { barley and oats }\end{array}$ & $\begin{array}{l}\text { Seed treatment } \\
\text { control }\end{array}$ & Cedomon & BioAgri AB \\
\hline
\end{tabular}




\begin{tabular}{|c|c|c|c|c|}
\hline P. flourescens & $\begin{array}{l}\text { Effective against } \\
\text { P. tolasi on } \\
\text { mushrooms and } \\
\text { Erwinia on fruit } \\
\text { crops }\end{array}$ & Antibacterial & $\begin{array}{l}\text { Conquer } \\
\text { Blight Ban } \\
\text { A506 }\end{array}$ & $\begin{array}{l}\text { Mauri Foods } \\
\text { NuFarm Inc }\end{array}$ \\
\hline $\begin{array}{l}P . \\
\text { solanacearum }\end{array}$ & $\begin{array}{l}\text { Bacterial control } \\
\text { in vegetables }\end{array}$ & Antibacterial & PSSOL & NPP, Korea \\
\hline P. syringae & $\begin{array}{l}\text { Effective against } \\
\text { post-harvest } \\
\text { pathogens on } \\
\text { apples, pears } \\
\text { and citrus }\end{array}$ & Antagonist & Bio-Save & $\begin{array}{l}\text { Het Harvest } \\
\text { Solutions }\end{array}$ \\
\hline $\begin{array}{l}\text { Pseudomonas } \\
+ \text { Azospirillum }\end{array}$ & $\begin{array}{l}\text { Effective against } \\
\text { brown patch and } \\
\text { dollar spot soil } \\
\text { pathogens }\end{array}$ & Antagonist & BioJet & Eco-Soil \\
\hline \multicolumn{5}{|c|}{ Fungi } \\
\hline $\begin{array}{l}\text { Ampelomyces } \\
\text { quisqualis }\end{array}$ & $\begin{array}{l}\text { Powdery mildew } \\
\text { control and } \\
\text { damping off } \\
\text { disease control }\end{array}$ & Hyperparasitic & $\begin{array}{l}\text { Q-Fect } \\
\text { Green-all }\end{array}$ & $\begin{array}{l}\text { Green Biotech, } \\
\text { Korea }\end{array}$ \\
\hline $\begin{array}{l}\text { Burkholderia } \\
\text { cepacia }\end{array}$ & $\begin{array}{l}\text { Effective against } \\
\text { soil fungal } \\
\text { pathogens }\end{array}$ & $\begin{array}{l}\text { Controls fungi } \\
\text { via seed } \\
\text { treatment }\end{array}$ & Deny & $\begin{array}{l}\text { Stine Microbial } \\
\text { Products }\end{array}$ \\
\hline $\begin{array}{l}\text { Candida } \\
\text { oleophila }\end{array}$ & $\begin{array}{l}\text { Effective against } \\
\text { postharvest } \\
\text { pathogens like } \\
\text { Botrytis and } \\
\text { Penicillium }\end{array}$ & $\begin{array}{l}\text { Colonization } \\
\text { of diseased } \\
\text { tissues }\end{array}$ & Aspire & Ecogen \\
\hline $\begin{array}{l}\text { Coniothyrim } \\
\text { minitans }\end{array}$ & $\begin{array}{l}\text { Effective against } \\
\text { Sclerotinia species } \\
\text { on canola, } \\
\text { sunflower, peanut, } \\
\text { soyabean and } \\
\text { vegetables }\end{array}$ & $\begin{array}{l}\text { Mode-of- } \\
\text { action not } \\
\text { clear }\end{array}$ & $\begin{array}{l}\text { Contans WG } \\
\text { KONI }\end{array}$ & $\begin{array}{l}\text { Prophyta } \\
\text { Biologischer } \\
\text { GmbH } \\
\text { BIOVED Ltd. }\end{array}$ \\
\hline $\begin{array}{l}\text { Fusarium } \\
\text { oxysporum } \\
\text { (non- } \\
\text { pathogenic) }\end{array}$ & $\begin{array}{l}\text { Effective against } \\
\text { pathogenic } \\
\text { Fusarium on basil, } \\
\text { carnation, } \\
\text { cyclamen, tomato }\end{array}$ & $\begin{array}{l}\text { Seed treatment } \\
\text { and soil } \\
\text { incorporation }\end{array}$ & $\begin{array}{l}\text { Biofox C } \\
\text { Fusaclean }\end{array}$ & $\begin{array}{l}\text { SIAPA } \\
\text { NPP, France }\end{array}$ \\
\hline $\begin{array}{l}\text { Gliocladium } \\
\text { catenulatum } \\
\text { Gliocladium } \\
\text { spp. }\end{array}$ & $\begin{array}{l}\text { Effective against } \\
\text { Pythium, } \\
\text { Rhizoctona, } \\
\text { Botrytis and } \\
\text { Didymella species } \\
\text { on greenhouse }\end{array}$ & $\begin{array}{l}\text { Mode-of- } \\
\text { action not } \\
\text { clear }\end{array}$ & $\begin{array}{l}\text { Primastop } \\
\text { GlioMix } \\
\text { Prestop }\end{array}$ & $\begin{array}{l}\text { Verdera Oy, } \\
\text { Finland } \\
\text { Fargo, UK }\end{array}$ \\
\hline
\end{tabular}




\begin{tabular}{|c|c|c|c|c|}
\hline & crops & & & \\
\hline $\begin{array}{l}\text { Gliocladium } \\
\text { virens }\end{array}$ & $\begin{array}{l}\text { Effective against } \\
\text { soil pathogens } \\
\text { causing damping } \\
\text { off and root rot }\end{array}$ & Antagonist & Soil Guard 12G & Certis LLC \\
\hline $\begin{array}{l}\text { Phelbia } \\
\text { gigantea }\end{array}$ & $\begin{array}{l}\text { Effective against } \\
\text { pine and spruce } \\
\text { rust }\end{array}$ & Biofungicide & Rotstop & Kemira \\
\hline $\begin{array}{l}\text { Phytophthora } \\
\text { palmivora } \\
\text { Pythium } \\
\text { oligandrum }\end{array}$ & $\begin{array}{l}\text { Vine strangler } \\
\text { Management of } \\
\text { fungal pathogens } \\
\text { in various crops }\end{array}$ & $\begin{array}{l}\text { Infects via } \\
\text { roots } \\
\text { Seed treatment } \\
\text { or soil } \\
\text { incorporation }\end{array}$ & $\begin{array}{l}\text { DeVine } \\
\text { Polyversum }\end{array}$ & $\begin{array}{l}\text { Abbott } \\
\text { Biopreparaty } \\
\text { Ltd., Czech }\end{array}$ \\
\hline $\begin{array}{l}\text { Streptomyces } \\
\text { griseoviridis }\end{array}$ & $\begin{array}{l}\text { Effective against } \\
\text { wilt, seed rot and } \\
\text { stem rot }\end{array}$ & Antagonist & $\begin{array}{l}\text { Mycostop } \\
\text { Mycostop Mix }\end{array}$ & $\begin{array}{l}\text { Verdera Oy and } \\
\text { Rincon Vitova }\end{array}$ \\
\hline $\begin{array}{l}\text { Streptomyces } \\
\text { lydicus }\end{array}$ & $\begin{array}{l}\text { Effective against } \\
\text { soil borne diseases } \\
\text { of turf, nursery } \\
\text { crops }\end{array}$ & Fungicide & Actinovate SP & $\begin{array}{l}\text { Natural Industries } \\
\text { Inc }\end{array}$ \\
\hline $\begin{array}{l}\text { Talaromyces } \\
\text { flavus V117b }\end{array}$ & $\begin{array}{l}\text { Effective against } \\
\text { fungal pathogens } \\
\text { of tomato, } \\
\text { cucumber, } \\
\text { strawberry and } \\
\text { rape oilseeds }\end{array}$ & Antagonist & Protus WG & $\begin{array}{l}\text { Peophyta } \\
\text { Biolgischer } \\
\text { Pflanzenschutz }\end{array}$ \\
\hline $\begin{array}{l}\text { Trichoderma } \\
\text { harzianum }\end{array}$ & $\begin{array}{l}\text { Effective against } \\
\text { variety of soil } \\
\text { pathogens and } \\
\text { wound pathogens }\end{array}$ & $\begin{array}{l}\text { Mycoparasitic, } \\
\text { Antagonistic }\end{array}$ & $\begin{array}{l}\text { RootShield } \\
\text { Bio Trek 22g } \\
\text { Supresivit }\end{array}$ & $\begin{array}{l}\text { Bio Works Inc } \\
\text { Wilbur-Ellis } \\
\text { Borregaard, } \\
\text { Denmark }\end{array}$ \\
\hline $\begin{array}{l}\text { T. harzianum }+ \\
\text { T.viride }\end{array}$ & $\begin{array}{l}\text { Effective against } \\
\text { Armillaria and } \\
\text { Botryoshaeria and } \\
\text { others }\end{array}$ & Mycoparasitic & $\begin{array}{l}\text { Trichopel } \\
\text { Trichojet } \\
\text { Trichodowels } \\
\text { Trichoseal }\end{array}$ & Agrimm Tech \\
\hline $\begin{array}{l}\text { Trichoderma } \\
\text { sp. }\end{array}$ & $\begin{array}{l}\text { Supresses root } \\
\text { pathogens }\end{array}$ & Mycoparasitic & $\begin{array}{l}\text { Trichodry } \\
\text { Trichoflow } \\
\text { Trichogrow } \\
\text { Trichopel } \\
\text { Vinevax }\end{array}$ & $\begin{array}{l}\text { Agrimm } \\
\text { Technologies } \\
\text { Ltd. New Zealand }\end{array}$ \\
\hline $\begin{array}{l}\text { Trichoderma } \\
\text { viride }\end{array}$ & $\begin{array}{l}\text { Effective against } \\
\text { rot diseases }\end{array}$ & Mycoparasitic & $\begin{array}{l}\text { Ecosom TV } \\
\text { Tricon }\end{array}$ & $\begin{array}{l}\text { Agri Life } \\
\text { GreenMax } \\
\text { Agro Tech } \\
\text { Ecosense labs }\end{array}$ \\
\hline
\end{tabular}

(*products discontinued, **products having EPA experiemental use permit) 
Fig.1 Biopesticides market size and forecast (2015-2024) in US\$ Billion

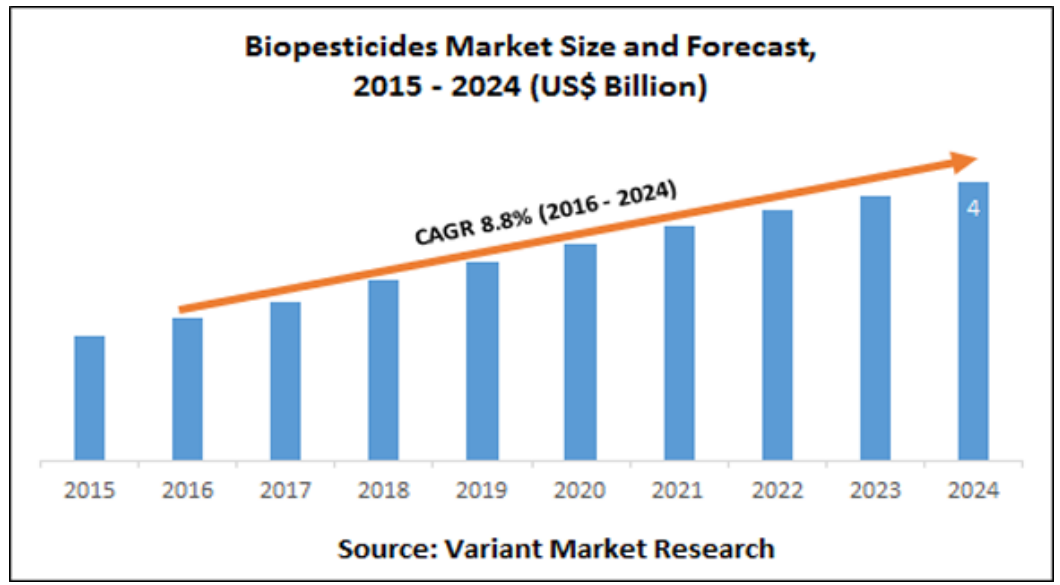

Fig.2 Growth of biopesticides on the basis of type

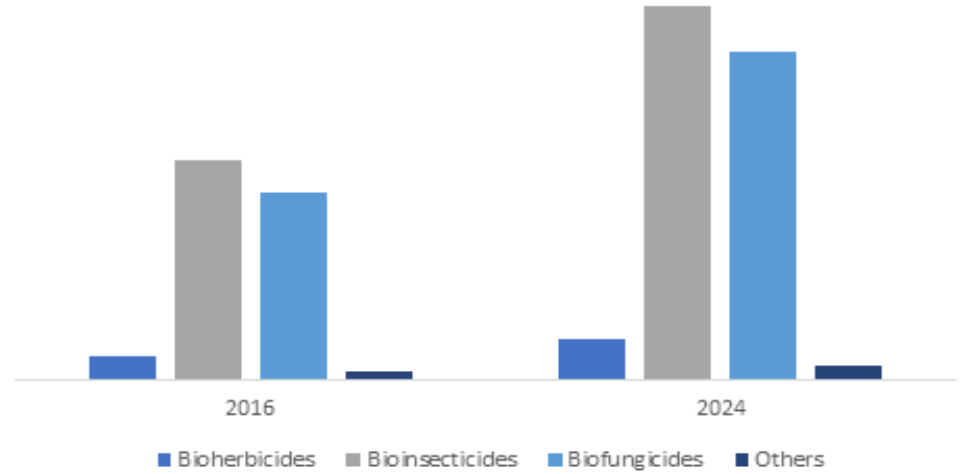

In fact, there is a need for well-defined selection criteria i.e. toxicity, production efficiency and safety of the product. Besides, most jurisdictions recognize that biopesticides are fundamentally different to synthetic pesticides. Concerted efforts to modify regulations will be crucial to boost development of new biopesticides. More research is required towards integrating biological agents into production system, improving capability of developing countries to manufacturing and commercialization of biopesticides. At the same time, it is also required to encourage public funded programmes, commercial investors and pesticide companies to take up biopesticide enterprises. Strict regulatory mechanisms to maintain the quality parameter and availability of the biopesticides at affordable cost in the developing countries must be followed. Thus, various aspects of biopesticides covering the current status, constraints, prospects and regulatory network towards their successful utilization for the benefit of people and environment need to be examined regularly.

Progress has clearly been made, with many new biopesticides on the market and technological developments continuing to overcome impediments. However, in our opinion, they have not yet reached their 
potential, even though all predictions suggest biopesticides will outperform other pest control options in terms of market share increases in the near future. We see a bright future for biopesticides, if the research and industry groups can think bigger and act united, better communicate the positive messages about biopesticides, and demonstrate their ability to control pests effectively and economically.

\section{References}

Arthurs, SP, Lacey LA, Rosa FDL (2008). Evaluation of granulovirus (PoGV) and Bacillus thuringiensis subsp. Kurstaki for control of the potato tuberworm (Lepidoptera: Gelechiidae) in stored tubers. Journal of Economic Entomology; 101: 1540-6.

Bailey, KL, Boyetchko SM, Langle T. (2010) .Social and economic drivers shaping the future of biological control: a Canadian perspective on the factors affecting the development and use of microbial biopesticides. Biological Control; 52: 221-9.

Biopesticides-market-research-report/669-

104.html (2015). India biopesticides market outlook to 2020- Trichoderma and Bacillus thuringiensis (BT) biopesticides to lead the future growth. https://www.kenresearch. com/agriculture-and-animal-care/cropprotection/india

Birch, A. N. E., Begg, G. S., and Squire, G. R. (2011). How agro-ecological research helps to address food security issues under new IPM and pesticide reduction policies for global crop production systems. J. Exp. Bot. 62, 3251-3261

Chen, R., (2014). Biopesticides: A Formulator's Perspective. http:// news. agropages. com / News/ NewsDetail--14156.
Clouston, A.M., Hill, R.A., Minchin, R., Braithwaite, M., Stewart, A., (2010). A bioassay screening Trichoderma isolates for enhancement of root development in Impatiens Walleriana cuttings. N. Z. Plant Prot. 63, 33-38

Cook, R, Baker K. (1983). The Nature and Practice of Biological Control of Plant Pathogens. St Paul, MN: Am. Phytopathol. Soc

Cuddeford, V. and Kabaluk, J.T. (2010). Alternative regulatory models for microbial pesticides. In The Use and Regulation of Microbial Pesticides in Representative Jurisdictions Worldwide (Kabaluk et al., eds), pp. 94-98, IOBC Global

Desai, S.T. (1997). Chemical industry in the post independence era: a finance analysis point of view. Chemical Business, $11(1)$ : 25 - 28. https://www.google.co.in/search?site= \&source $=h p \& q=w w w . f a o .+o r g \& o q=$ www.fao.+org\&gs

Glare, T.R. and O'Callaghan, M. (2000) Bacillus thuringiensis; Biology, Ecology and Safety, Wiley

Grewal, PS, Ehlers R-U, Shapiro-Ilan DI. (2005). Nematodes as Biological Control Agents. CAB International, Wallingford, UK.

Harman, G.E. (2011) Trichoderma-not just for biocontrol anymore. Phytoparasitica 39, 103-108 https://www.google.co.in/search?biw= $1366 \& b i h=613 \& q=w w w .+$ markets $+a$ nd+markets.com https://www.mordorintelligence.com/i ndustry-reports/indian-biopesticidesmarket-growth - trends-and-forecasts2014-2019-industry

Kabaluk, T, Gazdik K. (2007). Directory of microbial biopesticides for agricultural crops in OECD countries. http://www4.agr.gc.ca/ resources/prod /doc/pmc/ pdf/ micro.e.pdf. 
Kaya, HK, Gaugler R. (1993). Entomopathogenic nematodes. Annual Review of Entomology; 38:181-206.

Keswani, C, Bisen K, Singh V, Sarma B K, Singh HB (2015). Formulation technology of biocontrol agents: Present status and future prospects. Bioformulations: for Sustainable Agriculture. pp 35-52.

Khachatourians, GG. (2009). Insecticides, microbials. Applied Microbiology: Agro/ Food; 95-109.

Kiewnick, S. (2007). Practicalities of developing and registering microbial biological control agents. $\mathrm{CAB}$ Reviews: Perspectives in Agriculture Veterinary Science Nutrition and Natural Resources, No.013, CABI Publishing (http://www.cababstracts plus.org/cabreviews) (Date accessed: September 2011).

Klein, MG. (1990). Efficacy against soilinhabiting insect pests. In: Gaugler R, Kaya HK, editors. Entomopathogenic Nematodes in Biological Control. CRC Press, Boca Raton, FL; p. 195214.

Köhl, J., Postma J., Nicot P., Ruocco M., Blum B. (2011). Stepwise screening of microorganisms for commercial use in biological control of plant-pathogenic fungi and bacteria. Biol. Control 57, $1-12$

Koppenhofer, AM, Kaya HK. (2002). Entomopathogenic nematodes and insect pest management. In: Koul 0, Dhaliwal GS, editors. Microbial Biopesticides. Taylor \& Francis, London; p. 277-305.

Kristiofferesen P, Rask AM, Grundy AC, Franken I, Kempenaar C, Raison J (2008). A review of pesticide policies and regulations for urban amenity areas in seven European countries. Weed Research; 48: 201-14.

Lacey, LA, Headrick HL, Arthurs SP (2008).
Effect of temperature on long-term storage of codling moth granulovirus formulations. Journal of Economic Entomology 2008; 101: 288-94.

Leahy, J, Mendelsohn M, Kough J, Jones R, Berckes N (2014). Biopesticide oversight and registration at the U.S. Environmental Protection Agency. In: Coats (ed.) Biopesticides: state of the art and future opportunities. ACS Symposium Series, American Chemical Society: Washington, DC.

Marrone, P.G. (2002). An effective biofungicide with novel modes of action. Pestic. Outlook 13, 193-194

NAAS, Biopesticides - quality assurance, Policy Paper No. 62, National Academy of Agricultural Sciences, New Delhi, 2013, p. 20.

Oerke EC (2006). Crop losses to pests. J Agric Sci 144:31-43

Ownley, BH, Gwinn KD, Vega FE. (2010). Endophytic fungal entomopathogens with activity against plant pathogens: ecology and evolution. BioControl 55, $113-128$

PMRA. (2008). In: Update on Reduce Risk Pesticides in Canada, RR 2008-01. Health Canada Pest Management Regulatory Agency, Ottawa, Canada. http://www.pmra-arla.gc.ca.

Rawat L, Singh Y, Shukla N, Kumar J (2011). Alleviation of the adverse effects of salinity stress in wheat (Triticum aestivum L.) by seed biopriming with salinity tolerant isolates of Trichoderma harzianum. Plant and soil 347 (1-2), 387.

Roh, JY, Choi JY, Li MS, Jin BR, Je YH. (2007). Bacillus thuringiensis as a specific, safe, and effective tool for insect pest control. Journal of Microbiology and Biotechnology; 17:547-9.

Shapiro-Ilan, DI, Gouge DH, Koppenhofer AM. (2002). Factors affecting 
commercial success: Case studies in cotton, turf and citrus. In: Gaugler R, editor.

Entomopathogenic Nematology. CAB International, New York; p. 333-56.

Shukla, N, Awasthi RP, Rawat L, Kumar J (2012). Biochemical and physiological responses of rice (Oryza sativa L.) as influenced by Trichoderma harzianum under drought stress. Plant Physiol Biochem 54:78-88.

Singh, HB, Singh A, Sarma BK, Upadhyay DN (2014). Trichoderma viride $2 \%$ WP (Strain No. BHU-2953) formulation suppresses tomato wilt caused by Fusarium oxysporum f. sp. lycopersici and chilli damping-off caused by Pythium aphanidermatum effectively under different agroclimatic conditions. Int $\mathbf{J}$ Agri Environ Biotechnol 7:313-320

Thakore, Y. (2006). The biopesticide market for global use. Industrial Biotechnology, 2:194-208.

UN. World Population Prospects (2011). The
2010 Revision United Nations, New York.

Van Lenteren, J.C. (2012). The state of commercial augmentative biological control: plenty of natural enemies, but a frustrating lack of uptake. BioControl 57, 1-20

Weindling, R. (1932). Trichoderma lignorum as a parasite of other soil fungi. Phytopathology 22:837-45 142.

Weindling, R. (1934). Studies on a lethal principle effective in the parasitic action of Trichoderma lignorum on Rhizoctonia solani and other soil fungi. Phytopathology 24:1153-79

Williams, RN, Fickle DS, Grewal PS, Meyer JR. (2002). Assessing the potential of entomopathogenic nematodes to control the grape root borer Vitacea polistiformis (Lepidoptera: Sesiidae) through laboratory and greenhouse bioassays. Biocontrol Science and Technology; 12:35-42.

\section{How to cite this article:}

Nandani Shukla, Erayya Archana Negi Akansha Singh, B C. Kabadwa, Roopali Sharma and Jatinder Kumar. 2019. Present Status and Future Prospects of Bio-Agents in Agriculture. Int.J.Curr.Microbiol.App.Sci. 8(04): 2138-2153. doi: https://doi.org/10.20546/ijcmas.2019.804.251 